\title{
Anthropometric study on the role of yogurt fermented with Lactobacillus bulgaricus and Bifidobacterium animalis subsp. lactis in the prevention and treatment of obesity and related diseases
}

\section{DOI: http://doi.org/10.26758/8.1.17}

Svetoslav Handjiev (1), Aneliya Kuzeva (2)

(1) Medical University of Sofia; Bulgarian Association for the Study of Obesity and Related Diseases, Bulgaria

(2) Medical University of Sofia, Bulgaria, e-mail: aneliyakuzeva@gmail.com

Address correspondence to: Svetoslav Handjiev, e-mail: svhandjiev@ gmail.com

\begin{abstract}
Objectives. The role of yogurt, respectively probiotics, in the treatment and prevention of obesity has been discussed. The aim of our study was to investigate the effect of yogurt fermented with Lactobacillus bulgaricus and Bifidobacterium animalis subsp. lactis $(0.5 \%$ fat $)$ in the treatment of patients with obesity.
\end{abstract}

Material and methods. A total of 57 subjects with central type obesity (21 men and 36 women) were enrolled in the study. The baseline characteristics of the sample (average values) were the following: age -46.2 years, body mass index (BMI) - 35.4, fat mass $-39.4 \%$, visceral fat -14.1 , waist circumference $-109 \mathrm{~cm}$, hip circumference -120.2 , and sagittal diameter $-27 \mathrm{~cm}$. All these obese patients underwent a dietary regimen, included $290 \mathrm{~g}$ yogurt fermented with Lactobacillus bulgaricus and Bifidobacterium animalis subsp. lactis for dinner during a 6-month period. The product consisted of proteins $-4.3 \mathrm{~g}$, carbohydrates (lactose) $-3.9 \mathrm{~g}$, fat $-0.5 \mathrm{~g}$, and 37 kilocalories per $100 \mathrm{~g}$ product. At the beginning and at the end of the study, several anthropometric parameters have been measured using a bioimpedance device (Tanita 420).

Results. The study demonstrated the decrease of BMI with $9.8 \%$, of fat mass with $9.6 \%$, of visceral fat with $14 \%$, as well as a decrease in waist circumference by $11.9 \%$, of hip circumference by $5.8 \%$, and of sagittal diameter by $10.3 \%$.

Discussion: Probiotics are substances that regulate the normal intestinal flora, influence metabolism and have an effect on various diseases. Our studies were performed on the effect of Lactobacillus Bulgaricus and Bifidobacterium animalis subsp. lactis on carbohydrate and lipid metabolism in obesity. The results indicated that the probiotics improved the impaired glucose and lipid metabolism. The probiotics affected the concentration of free radicals in the blood. Taken together, the results give a reason to assume that the effect of probiotics on oxidative stress in the mechanism of influence on the metabolism is important.

Conclusion. The regular consumption of yogurt fermented with Lactobacillus bulgaricus and Bifidobacterium animalis subsp. lactis $(0.5 \%$ fat $)$ in the diet of obese patients leads to improvement of the studied anthropometric parameters as well as to significant decrease in the cardiovascular risk.

Keywords: anthropometric study; yogurt; probiotics; metabolic syndrome. 


\section{Introduction}

Obesity is a chronic metabolic disease that leads to many co-morbidities and high prevalence of mortality (Yumuk et al., 2015; WHO, 2018). The incidence of obesity and related diseases increases constantly (see Figs. 1-4). The role of dairy products in the treatment and prevention of obesity has been discussed (Bogdanov, 2014; Martinez-Gonzalez et al., 2014; Ahn et al., 2015; Handjieva-Darlenska et al.,-2015; Handjieva-Darlenska et al., 2016; Lamarche et al., 2016; Beck et al., 2017). The literature also highlighted the effect of yogurt, respectively probiotics, in the treatment and prevention of obesity (Bogdanov, 2014; Handjieva-Darlenska and Minkova, 2016; Santiago et al., 2016; Karimi et al., 2017).

Figure 1. Expected increase in the incidence of obesity.

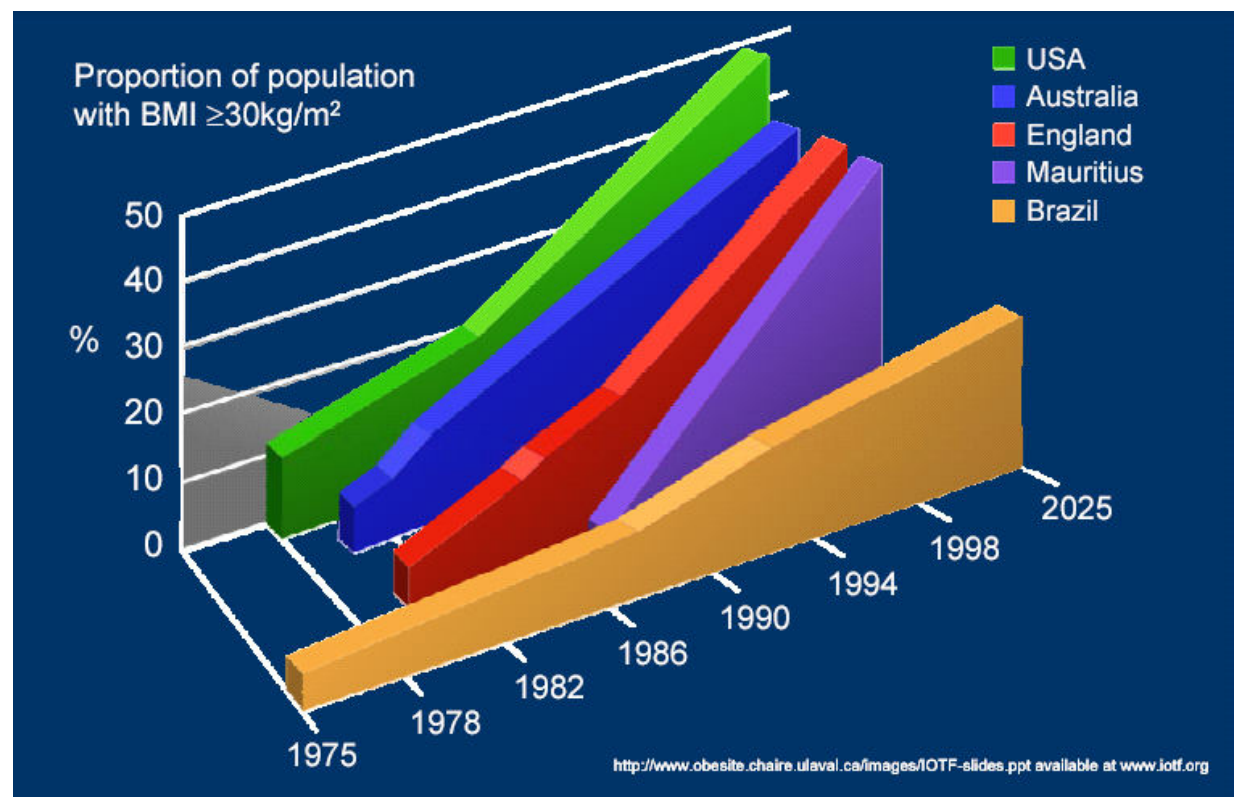

Figure 2. Expected increase in the incidence of diabetes.

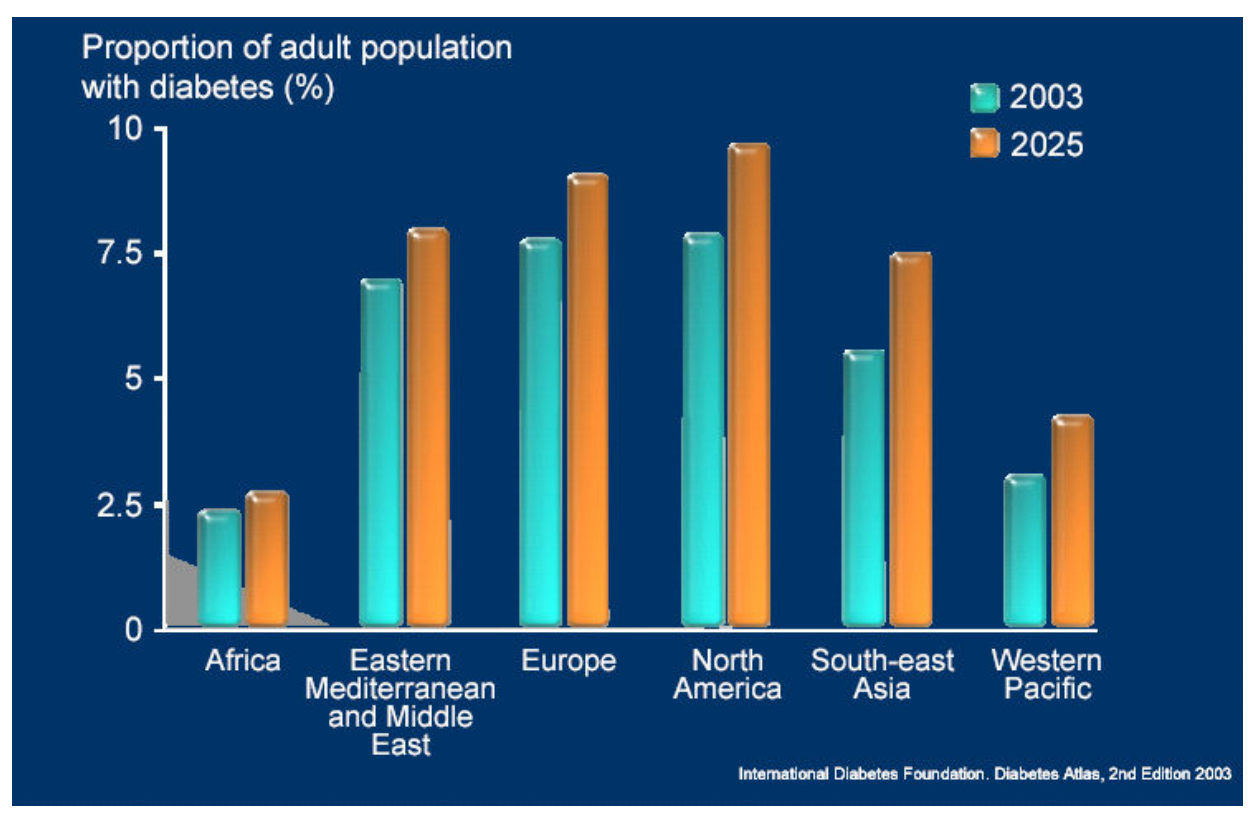


Figure 3. Overweight and obesity prevalence in schoolchildren. National survey on nutrition and nutritional status of schoolchildren in Bulgaria -1998, 2010-2011 (Source: Dimitrova, 2012).

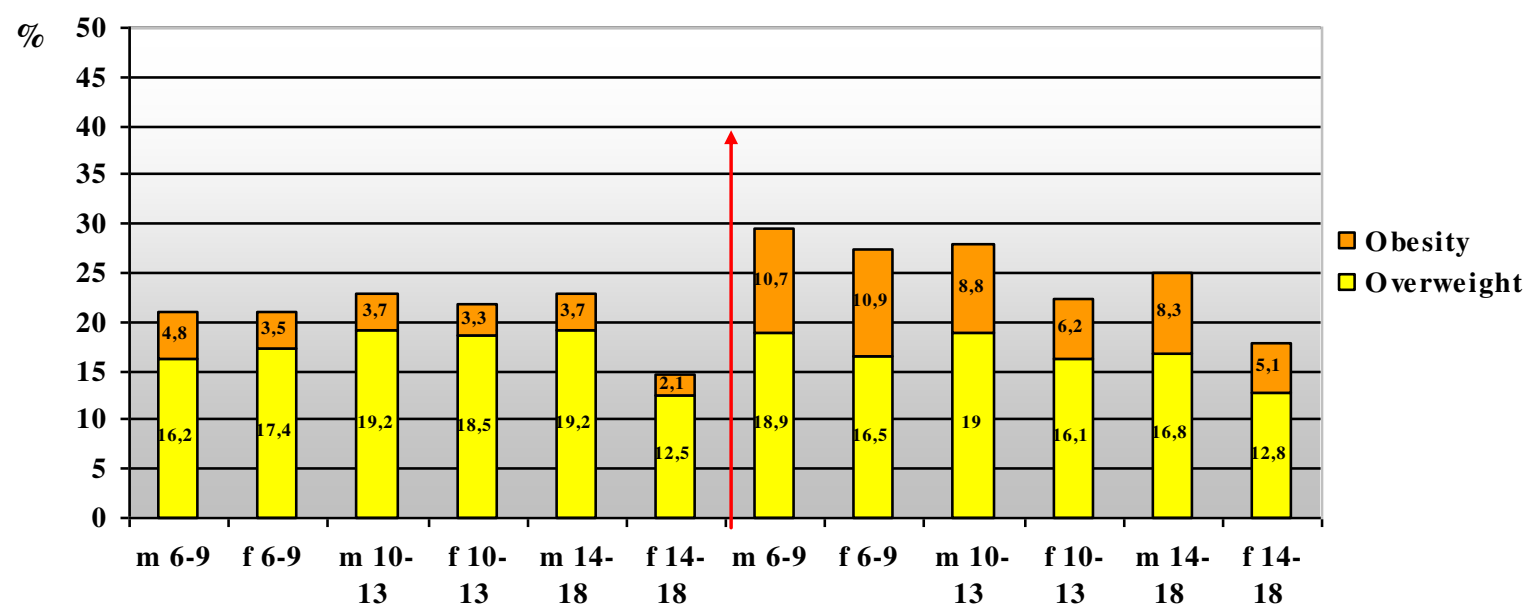

Figure 4. Prevalence of Overweight and Obesity among adults (19-60 years old). National Monitoring of Dietary Intake and Nutritional Status, 1998, 2004 (Source: Dimitrova, 2012).

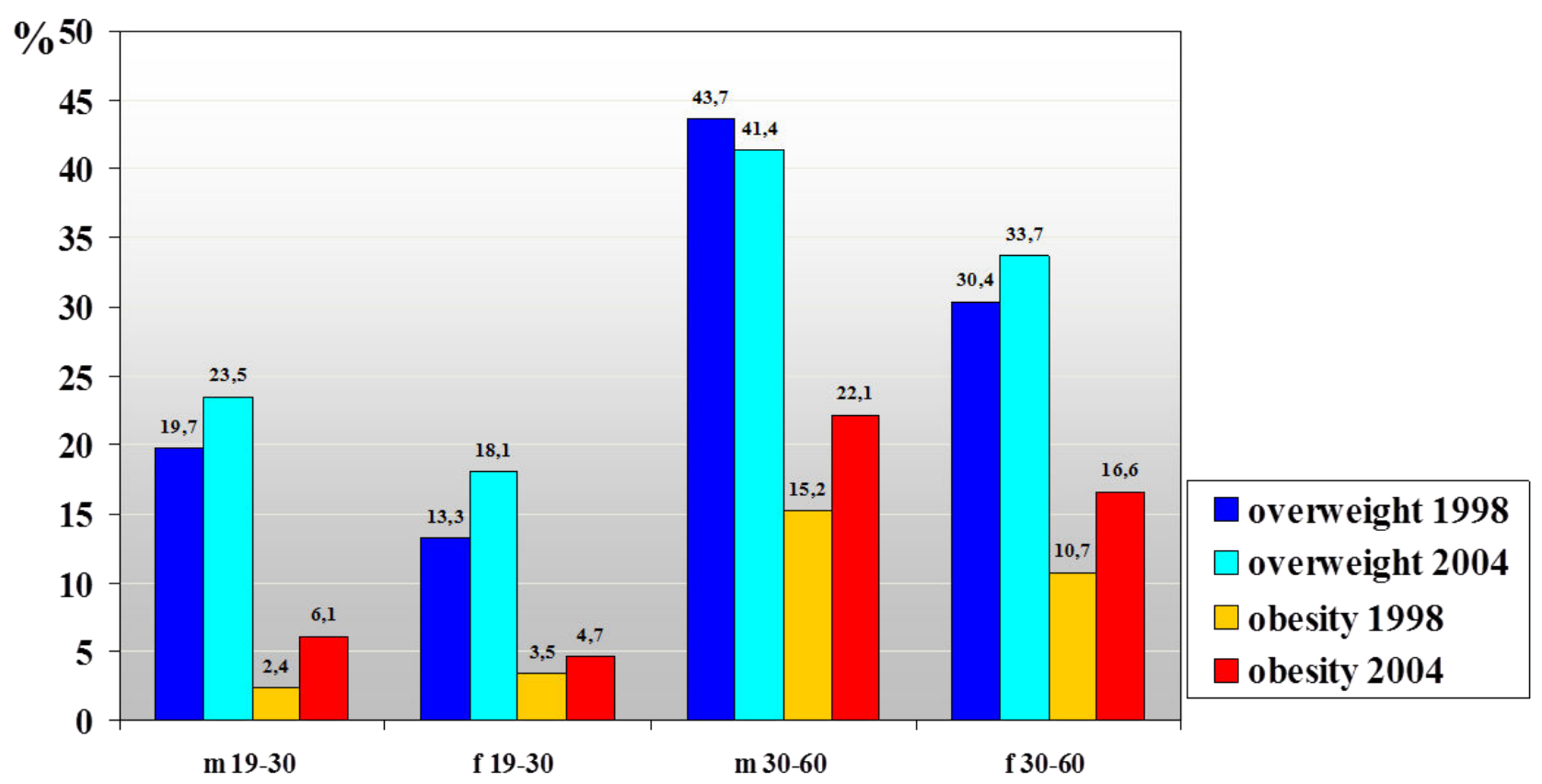

Age (years) 


\section{History}

Even since the end of $19^{\text {th }}$ century, the Russian scientist and pioneer immunologist Ilya Ilyich Mechnikov (or Elie Metchnikoff, as his name is often written), investigating the factors that could enhance or decrease health and longevity, advanced the idea of the harmful intestinal bacteria as the source of the inflammatory process; the thermal preparation of all fruits and vegetables and the regular consumption of yogurt or other types of sour milk were proposed as solutions for the intestinal putrefaction that precipitated the aging process. He emphasized, in particular, the positive, neutralization effect of the so-called Bulgarian Bacillus from the Bulgarian yogurt upon intestinal microbiome, as proven by the health and longevity of the highlanders who include large amounts of soured milk in their diet.

The actual discovery of the Lactobacillus bulgaricus is due to Stamen Grigoroff, a Bulgarian student who studied medical science in Geneva, Switzerland. Immediately after he identified the bacteria that cause the milk to curdle, his professor, Léon Massol wrote to Prof. Ilyja Mechnikoff at the Institut "Louis Pasteur", announcing the great scientific results. His discovery was presented in the paper entitled "Etude sur le lait fermenté comestible: le "Kissélo-mléko" de Bulgarie" and published in Revue médicale de la Suisse romande: organe officiel de la Société médicale de la Suisse romande, issue 10, dated 20.10.1905, Genève, Georg \& G., Libraries-Éditeurs. Librairie de L'Université. Then, it was validated by Metchnikoff, who invites the young scientist to Paris; his assistants, Luerssen and Kuhn, were those who in 1908 gave to this microorganism the designation of Lacto bacterium Bulgaricum - the Bulgarian lactic bacteria.

Subsequently, the benefits of yogurt consumption have been the subject of numerous studies, eventually leading to the establishment of a Bulgarian school. For obtaining his medical degree of Doctor of Medicine in Toulouse, Radush Titkov defended in 1905 a thesis regarding the healthy properties of yogurt. Prof. Assen Zlatarov, who got his Ph.D. in Chemistry and Physics at the prestigious Grenoble University, called the yogurt "an elixir of long-life".

Academician Tasho Tashev, the dean of Bulgarian nutrition science, and his school (19802001) investigated the role of dairy foods in the prevention and treatment of the gastrointestinal and metabolic diseases (von Sanchsen, 2006; Handjieva-Darlenska, 2016).

\section{Aim}

The aim of our study was to investigate the effect of yogurt fermented with Lactobacillus bulgaricus and Bifidobacterium animalis subsp. lactis $(0.5 \%$ fat $)$ in the treatment of patients with obesity and related diseases.

\section{Material and methods}

A total of 57 subjects with central type obesity (21 men and 36 women) were enrolled in the study. The study took place in the National Transport Medical Hospital as part of the BARORD's (Bulgarian Association for Study of Obesity) activities. The participants were volunteers who took part in the study for 6 months and were consulted every 2 weeks throughout the study as part of the outpatient clinics.

The methods involved anthropometrical measurements to determine the initial status of patients and to evaluate the results of the dietary regimen imposed to all the obese patients.

All obese patients underwent a dietary regimen, included $290 \mathrm{~g}$ yogurt fermented with Lactobacillus bulgaricus and Bifidobacterium animalis subsp. lactis for a 6-month period which 
replaced their regular dinner. The product consisted of proteins $-4.3 \mathrm{~g}$, carbohydrates (lactose) $3.9 \mathrm{~g}$, fat $-0.5 \mathrm{~g}$, and 7 kilocalories per $100 \mathrm{~g}$ yogurt product.

The classification of patients in the obesity weight classes was made considering the body mass index developed by Adolphe Quetelet and recommanded by WHO for estimating body fat mass. It is calculated by dividing the subject's mass by the square of his or her height. Any BMI $\geq$ 35 or 40 signals severe obesity; a BMI of $\geq 35$ or $40-44.9$ or 49.9 represents morbid obesity; a BMI of $\geq 45$ or 50 indicates a super obese. However, since the BMI does not reveal the body fat distribution, other measurements regarding body fat percentage had to be done.

Body height was measured using an anthropometer in the upright position.

Some parameters such as body weight, body mass index, body fat mass, visceral fat, lean body mass were assessed using a bioimpedance device (Tanita 420).

Sagital diameter was measured using a caliper.

\section{Results}

The baseline characteristics of the sample (average values) were the following: age -46.2 years, body mass index (BMI) -35.4 , fat mass $-39.4 \%$, visceral fat -14.1 , waist circumference $109 \mathrm{~cm}$, hip circumference $-120.2 \mathrm{~cm}$, and sagittal diameter $-27 \mathrm{~cm}$.

The study demonstrated the decrease of BMI with $9.8 \%$, of fat mass with $9.6 \%$, of visceral fat with $14 \%$, as well as a decrease in waist circumference by $11.9 \%$, of hip circumference by $5.8 \%$, and of sagittal diameter by $10.3 \%$ (see Table 1 ).

Moreover, at the end of treatment, we observed an improvement trend in the values of blood sugar, total cholesterol, triglycerides as well as of the systolic and diastolic blood pressure.

Table 1. Changes in physical parameters following treatment

\begin{tabular}{|c|c|c|c|c|c|c|c|c|c|}
\hline Parameter & $B M I$ & $\begin{array}{c}F M \\
(\%)\end{array}$ & $\begin{array}{c}L B M \\
(\%)\end{array}$ & $L B M / F M$ & $V F$ & $\begin{array}{c}W \\
(\mathrm{~cm})\end{array}$ & $\begin{array}{c}H \\
(\mathrm{~cm})\end{array}$ & $\begin{array}{c}\text { Sag. } \\
\text { diameter }\end{array}$ \\
\hline $\begin{array}{c}\text { Before } \\
\text { treatment }\end{array}$ & 36.1 & 40.7 & 59.3 & 1.45 & 13 & 109.5 & 122.6 & 0.90 & 24.7 \\
\hline $\begin{array}{c}\text { After } \\
\text { Treatment }\end{array}$ & 32.2 & 36.2 & 63.8 & 1.80 & 11 & 98 & 114.6 & 0.87 & 22.8 \\
\hline
\end{tabular}

\section{Discussions}

Probiotics are substances that regulate the normal intestinal flora, influence metabolism and have an effect on various diseases. Our studies were performed on the effect of Lactobacillus bulgaricus and Bifidobacterium animalis subsp. lactis on carbohydrate and lipid metabolism in obesity. The results indicated that the probiotics improved the impaired glucose and lipid metabolism. The probiotics affected the concentration of free radicals in the blood. Taken together, 
the results demonstrate the effect of probiotics on oxidative stress in the mechanism of influencing carbohydrate and lipid metabolism.

Our study emphasizes the significance of yoghurt and other diary product in the prevention and management of metabolic and cardiovascular diseases, which is in concordance with other results found in the literature (Dimitrova, 2012; Milici and Neagu, 2014; Borys et al., 2015; Ivey et al., 2015; Pashova-Baltova et al., 2015; Santiago et al., 2016; Mohammadi-Sartang et al., 2018).

The production of fermented foods is based on the use of starter cultures, for eg. lactic acid bacteria, which initiate the rapid acidification of the raw material, i.e. the milk. A series of studies on the properties of lactic acid producing bacteria have reported suitable strains for inclusion in functional (starter) cultures and fermented products; among them we list L. bulgaricus strains with established in-vitro immunomodulatory effect, L. helveticus - producer of bioactive peptides with ACE-inhibitory activity, L. Gasseri - with a strong adhesion to the epithelial cells of the gastrointestinal tract and cholesterol-lowering effect.

Recently, new starter cultures of lactic bacteria are developed, which may contribute to microbial safety or provide one or more organoleptic, technological, nutritional or health benefits. Examples are the lactic acid bacteria that produce antimicrobial substances, sugar polymers, sweeteners, aromatic compounds, vitamins or enzymes useful or having probiotic properties (Leroy and De Vuyst, 2004).

\section{Conclusion}

The regular consumption of yogurt fermented with Lactobacillus bulgaricus and Bifidobacterium animalis subsp. lactis $(0.5 \%$ fat $)$ in the diet of obese patients leads to improvement of the studied anthropometric parameters as well as to significant decrease in the cardiovascular risk.

\section{References}

1. Beck, A.L., Heyman, M., Chao, C., Wojcicki, J., 2017. Full fat milk consumption protects against severe childhood obesity in Latinos. Preventive medicine reports, 8, pp.1-5. https://doi.org/10.1016/j.pmedr.2017.07.005

2. Lamarche, B., Givens, D.I., Soedamah-Muthu, S., Krauss, R.M., Jakobsen, M.U., BischoffFerrari, H.A., Pan, A., Després, J.P., 2016. Does Milk Consumption Contribute to Cardiometabolic Health and Overall Diet Quality? The Canadian journal of cardiology, 32(8), pp.1026-32. https://doi.org/10.1016/j.cjca.2015.12.033

3. Dimitrova, D., 2012. Overweight and obesity prevalence in Bulgaria. In: the EPODE INTERNATIONAL NETWORK, Global obesity Forum, New York, U.S., 27-29 June 2012.

4. Bogdanov, G., 2014. Probiotic as antioxidant in juvenile rats' fat-rich diet, Obesity facts, 7(supp.1), pp.66-67. Available at: https://bib.irb.hr/datoteka/703185.obesity_facts_2014.pdf [Accessed 26 June 2017]

5. Karimi, G., Jamaluddin, R., Mohtarrudin, N., Ahmad, Z., Khazaai, H., Parvaneh, M., 2017. Single-species versus dual-species probiotic supplementation as an emerging therapeutic strategy for obesity. Nutrition, metabolism, and cardiovascular diseases : NMCD, 27(10), pp.910-918. https://doi.org/10.1016/j.numecd.2017.06.020

6. Ahn, H.Y., Kim, M., Ahn, Y.T., Sim, J.H., Choi, I.D., Lee, S.H., Lee J.H. 2015. The triglyceride-lowering effect of supplementation with dual probiotic strains, Lactobacillus curvatus HY7601 and Lactobacillus plantarum KY1032: Reduction of fasting plasma lysophosphatidylcholines in nondiabetic and hypertriglyceridemic subjects. Nutrition, 
metabolism, and cardiovascular diseases: NMCD, 25(8), pp.724-33. https://doi.org/10.1016/j.numecd.2015.05.002

7. Borys, J.-M., Graça, P., Gregorio, M.J., Handjiev, Sv., Mantziki, K., Moreno, L.A., du Plessis, H.R., Seidell, J.C., Vassilopoulos, A., Visscher, T.,eds. 2015. EPODE for the Promotion of Health Equity, Cachan Cedex, France: Lavoisier Publishing.

8. Pashova-Baltova, K., Minkova, Sv., Dimitrov, Zh., Mihaylova, M., Spasova, M., Panayotova, T., Ninova, N., 2015. LB fermented functional foods - contributing to the prevention of obesity. In: BASORD (Bulgarian Association for Study of Obesity and Related Diseases), 14th International Symposium „Acad. Tasho Tashev”-“Nutrition and Obesity”, Albena, Bulgaria, 4-6 Septembrie 2015.

9. Ivey, K.L., Hodgson, J.M., Kerr, D.A., Thompson, P.L., Stojceski, B., Prince, R.L., 2015. The effect of yoghurt and its probiotics on blood pressure and serum lipid profile; a randomised controlled trial. Nutrition, metabolism, and cardiovascular diseases: NMCD, 25(1), pp.46-51. https://doi.org/10.1016/j.numecd.2014.07.012.

10. Leroy, F. and De Vuyst, L., 2004. Lactic acid bacteria as functional starter cultures for the food fermentation industry. Trends in Food Science \& Technology, 15(2), pp.67-78.

11. Mohammadi-Sartang, M., Bellissimo, N., Tötösy de Zepetnek, J.O., Brett, N.R., Mazloomi, S. M., Fararouie, M., Bedeltavana, A., Famouri, M., Mazloom, Z., The effect of daily fortified yogurt consumption on weight loss in adults with metabolic syndrome: a 10-week randomized controlled trial, Nutrition, Metabolism and Cardiovascular diseases, 2018, in press, Available online 10 March 2018. https://doi.org/10.1016/j.numecd.2018.03.001.

12. Martinez-Gonzalez, M.A., Sayon-Orea, C., Ruiz-Canela, M., de la Fuente, C., Gea, A., BesRastrollo, M., 2014. Yogurt consumption, weight change and risk of overweight/obesity: the SUN cohort study. Nutrition, metabolism, and cardiovascular diseases: NMCD, 24(11), pp.1189-96, https://doi.org/10.1016/j.numecd.2014.05.015.

13. Milici, N. and Neagu, A., 2014. La consommation de produits laitiers et l'état pondéral chez les adolescents de Bucarest, In: Mondialisation des comportements alimentaires et facteurs de risques pour l'obésité et le diabète, Sofia: Simel Press Edt. pp.101-115.

14. Santiago, S., Sayón-Orea, C., Babio, N., Ruiz-Canela, M., Martí, A., Corella, D., Estruch, R., Fitó, M., Aros, F., Ros, E., Gómez-García, E., Fiol, M., Lapetra, J., Serra-Majem, L., BecerraTomás, N., Salas-Salvadó, J., Pinto, X., Schröder, H., Martínez, J.A., 2016. Yogurt consumption and abdominal obesity reversion in the PREDIMED study. Nutrition, metabolism, and cardiovascular Niseases: NMCD, 26(6), pp.468-75. https://doi.org/10.1016/j.numecd.2015.11.012.

15. Handjieva-Darlenska T., Fr. Roville-Sausse, Sv. Handjieva. 2016. Le yaourt- la diete balkanique. In: Nutrition et Sante. Sofia: Simel Press. pp.52-53.

16. Handjieva-Darlenska, T., Handjiev, Sv., Bogdanov, G., Lazarov, L., Getova, D., Stavreva, G., Boyadjieva, N., 2015. Characteristics of the low calorie diet with Probiotic for prophylaxis of diabetes mellitus type 2 in subjects with obesity and prediabetes. In: BASORD (Bulgarian Association for Study of Obesity and Related Diseases), $14^{\text {th }}$ International Symposium Acad. Tasho Tashev "Nutrition and Obesity", Albena, Bulgaria, 4-6 Sep 2015.

17. Handjieva-Darlenska, T. and Minkova, Sv., 2016. Clinico-Pharmacological, anthropological and technological study on the effect of new Bulgarian probiotic producs, In: A. Cosma si C. Glavce, eds. Antropologie şi sănătate (Anthropology and Health), Bucureşti: Editura Academiei Române. pp. 108-110. 
18. von Sanchsen, Th., The Balkan diet - Western Medicine Point of View. In: BASORD (Bulgarian Association for Study of Obesity and Related Diseases), $2^{\text {nd }}$ Balkan Congress on Obesity, Albena, Bulgaria, 19-21 May 2006, Abstract Booklet p. 70.

19. Yumuk, V., Tsigos, C., Fried, M., Schindler, K., Busetto, L., Micic, D., Toplak, H., Obesity Management Task Force of the European Association for the Study of Obesity, 2015. European Guidelines for Obesity Management in Adults. Obesity facts, 8(6), pp.402-24. https://doi.org/10.1159/000442721.

20. ***World Health Organization, 2018. Global Health Observatory (GHO) data. Overweight and obesity. Available at: http://www.who.int/gho/ncd/risk factors/overweight_obesity/obesity_adolescents/en/ [Accessed 20 March 2018] 